STATE OF ALASKA

DEPARTMENT OF NATURAL RESOURCES

Alaska Geologic Materials Center Data Report No. 422

\title{
No. 422
}

Dixit, N. and Tomsich, C. 2014, Apatite fission track, magnetic susceptibility, and vitrinite reflectance analyses on cuttings from the Nunivak \#1 and Nenana \#1 wells.

Zip file available for download

Received January 2014

All data reports may be downloaded free of charge from the DGGS website. 